\title{
The relationship between superior vena caval and mixed venous saturations after cardiac surgery
}

\author{
H Gasparovic ${ }^{1 *}$, R Gabelica², Z Ostojic ${ }^{3}$, T Kopjar $^{1}$, M Petricevic ${ }^{1}$, B Biocina ${ }^{1}$ \\ From 23rd World Congress of the World Society of Cardio-Thoracic Surgeons \\ Split, Croatia. 12-15 September 2013
}

\section{Background}

Global tissue hypoxia portends poor outcomes. Detection and prompt interventions designed to counter the effects of inadequate tissue perfusion are paramount. The relationship between venous saturations in different venous pools remains elusive and dependent upon the patient's hemodynamic status.

\section{Methods}

Venous samples were drawn from the superior vena cava $\left(\mathrm{S}_{\mathrm{SvC}} \mathrm{O}_{2}\right)$ and pulmonary artery $\left(\mathrm{MvO}_{2}\right)$ at three different time points (prior to operation (T0), immediately after weaning from $\mathrm{CPB}(\mathrm{T} 1)$ and on postoperative day 1 (T2)) from 89 consecutive cardiac surgical patients. Thermodilution cardiac indices and serum lactate measurements were obtained. Clinical outcomes were monitored.

\section{Results}

The difference between the $\mathrm{MvO}_{2}$ and $\mathrm{S}_{\mathrm{SvC}} \mathrm{O}_{2}$ widened over the monitored period $(0.08 \pm 8.66$ at $\mathrm{T} 0,-1.17 \pm 7.62$ at $\mathrm{T} 1$ and $-3.12 \pm 5.88$ at T2). Patients with a larger postoperative negative $\mathrm{MvO}_{2}-\mathrm{S}_{\mathrm{SVC}} \mathrm{O}_{2}$ gradient had longer $\mathrm{CPB}$ and cross-clamp times $(122 \pm 74$ vs. $97 \pm 40, \mathrm{P}=$ 0.08 ; $87 \pm 48$ vs. $68 \pm 26, \mathrm{P}=0.04$ ). This did not correlate with inferior clinical outcomes or laboratory markers of hypoperfusion.

\section{Conclusion}

The relationship between the venous saturations between different venous pools was inconsistent over the course of the immediate postoperative period, with a tendency towards expansion of the negative $\mathrm{MvO}_{2}$ -

\footnotetext{
* Correspondence: hgasparovic@gmail.com

'Department of Cardiac Surgery University Hospital Center Zagreb, Zagreb, Croatia

Full list of author information is available at the end of the article
}

$\mathrm{S}_{\mathrm{SVC} \mathrm{O}_{2}}$ gradient. Widening of the gradient between $\mathrm{MvO}_{2}$ and $\mathrm{S}_{\mathrm{SvC}} \mathrm{O}_{2}$ in favor of the latter correlated with the duration of the $\mathrm{CPB}$ and ischemic times. Extrapolating functional cardiac performance based on $\mathrm{S}_{\mathrm{SVC}_{\mathrm{C}}} \mathrm{O}_{2}$ would be unreliable in this setting, with greater errors seen following more complex operations.

\section{Authors' details}

${ }^{1}$ Department of Cardiac Surgery University Hospital Center Zagreb, Zagreb, Croatia. ${ }^{2}$ Department of Anesthesiology and Critical Care Medicine, University Hospital Zagreb, Zagreb, Croatia. ${ }^{3}$ The University of Zagreb, School of Medicine, Zagreb, Croatia.

Published: 11 September 2013

\section{doi:10.1186/1749-8090-8-S1-P62}

Cite this article as: Gasparovic et al:: The relationship between superior vena caval and mixed venous saturations after cardiac surgery. Journal of Cardiothoracic Surgery 2013 8(Suppl 1):P62.
Submit your next manuscript to BioMed Central and take full advantage of:

- Convenient online submission

- Thorough peer review

- No space constraints or color figure charges

- Immediate publication on acceptance

- Inclusion in PubMed, CAS, Scopus and Google Scholar

- Research which is freely available for redistribution
( Biomed Central

\section{(Ciomed Central}

